\title{
PENGEMBANGAN MODUL ELEKTRONIK DENGAN PENDEKATAN SAINTIFIK POKOK BAHASAN HUKUM TERMODINAMIKA UNTUK SMA/MA KELAS XI
}

\author{
Rahmiyati $^{1}$, M.Hidayat ${ }^{2}$, dan Darmaji ${ }^{3}$ \\ ${ }^{1,2,3}$ Program Studi Pendidikan Fisika FKIP Universitas Jambi, Jambi, Indonesia \\ Email: rahmiyati731@gmail.com
}

Info Artikel

Alamat Korespondensi:

Email:rahmiyati731@gmail.com

\begin{abstract}
Abstrak:
Penelitian ini bertujuan untuk mengembangkan modul elektronik dengan pendekatan saintifik pada materi hukum termodinamika dan mengetahui persepsi siswa terhadap modul elektronik. Jenis penelitian ini adalah penelitian dan pengembangan (research and development) dengan model pengembangan ADDIE. Tahapan yang ada pada model pengembangan ADDIE adalah analyze, design, development, implementation, dan evaluation.Penelitian ini dibatasi sampai tahapan development. Subjek uji coba dalam penelitian ini ialah siswa kelas XI MIPA 5 dan XI MIPA 1 SMAN 1 Muaro Jambi. Instrumen penelitian yang digunakan adalah observasi, telaah dokumen, angket kebutuhan siswa, angket validasi ahli media, angket validasi ahli materi dan angket persepsi siswa. Teknik analisis data kualitatif yang berupa observasi dan telaah dokumen dilakukan secara deskriptif kualitatif, saran dari validator ahli media dan ahli materi juga dilakukan secara deskriptif kualitatif, sedangkan skor angket validasi ahli media, ahli materi, dan persepsi siswa dilakukan secara statistik deskriptif dengan penyajian data melalui tabel). Spesifikasi produk yaitu software menggunakan $3 D$ PageFlip Professional, format akhir program .exe, kegiatan pembelajaran modul disusun dengan pendekatan saintifik, materi disajikan dengan persamaan yang jelas, gambar, grafik, video, animasi, simulasi, contoh soal dan latihan soal. Keunggulan yang terdapat pada modul elektronik yaitu modul ditampilkan dalam bentuk tiga dimensi, kegiatan pembelajaran disusun agar siswa dapat mengkonstruksi konsep, hukum atau prinsip melalui tahapan pembelajaran. Hasil validasi ahli media dan ahli materi terhadap modul elektronik dengan pendekatan saintifik pokok bahasan hukum termodinamika yaitu 69 dan 28 termasuk dalam kategori sangat baik dan baik. Hasil analisis dari persepsi siswa pada uji coba diperoleh skor rata-rata indikator keseluruhan adalah 72,53 dikategorikan sangat baik. Berdasarkan hasil tersebut dapat disimpulkan bahwa modul elektronik dengan pendekatan saintifik pokok bahasan hukum termodinamika layak digunakan sebagai salah satu bahan pembelajaran dan dapat diujicobakan dalam pembelajaran secara langsung.
\end{abstract}

Kata Kunci: Modul Elektronik, Pendekatan Saintifik 


\section{Pendahuluan}

Pada masa sekarang ini Fisika merupakan pelajaran yang kurang disenangi oleh sebagaian siswa hal ini dikarenakan siswa menganggap pelajaran Fisika itu penuh dengan teori dan persamaan-persamaan yang hanya dapat dimengerti oleh yang memiliki kemampuan lebih saja, hal ini didasarkan pada penelitian terdahulu. Misalnya penelitian yang dilakukan Ornek et.al. (2008) dalam Sulistyarini (2015) penelitian tersebut menghasilkan kesimpulan umum bahwa "sebagian besar siswa menganggap Fisika itu sulit karena mereka kurang memahami persamaan, hubungan antara grafik dan rumusan matematisnya". Penelitian ini didukung oleh penelitian yang dilakukan Indana Zulfa (2013) dalam Hidayatulloh (2014) yang menunjukkan bahwa dari 210 siswa yang dijadikan sampel penelitian ditemukan sebanyak $64,95 \%$ siswa mengalami salah konsep tentang usaha dalam termodinamika, 31,07 \% siswa tentang Hukum I Termodinamika, dan 3,98\% siswa tentang hukum II termodinamika. Kesalahan konsep yang ditemukan, antara lain: (1) mengidentifikasi usaha terbesar atau terkecil pada sebuah sistem, (2) mengidentOifikasi usaha yang bernilai postif atau negatif, dan (3) menjelaskan pengaruh kalor terhadap perubahan energi dalam pada proses isokorik. Padahal pelajaran ini merupakan suatu kunci untuk memahami gejala-gejala yang berhubungan dengan kehidupan sehari-hari.

Salah satu solusi untuk mengatasi permasalahan di atas adalah dengan mengembangkan bahan ajar yang memanfaatkan kemajuan tekhnologi di era globalisasi ini, salah satunya yaitu modul elektronik. Modul merupakan salah satu bentuk bahan ajar yang dikemas secara utuh dan sistematis, didalamnya memuat seperangkat pengalaman belajar yang terencana dan didesain untuk membantu peserta didik menguasai tujuan belajar yang spesifik. Modul minimal memuat tujuan pembelajaran, materi/substansi belajar, dan evluasi. Modul berfungsi sebagai sarana yang bersifat mandiri, sehingga peserta didik dapat belajar secara mandiri sesuai kecepatannya masing-masing. (Daryanto, 2013). Sedangkan Modul elektronik adalah sebuah bentuk penyajian bahan belajar mandiri yang disusun secara sistematis ke dalam unit pembelajaran terkecil untuk mencapai tujuan pembelajaran tertentu yang disajikan ke dalam format elektronik yang di dalamnya terdapat animasi, audio, navigasi yang membuat pengguna lebih interaktif dengan program (Sugianto, 2013). Modul elektronik pada dasarnya dalam struktur penulisannya mengadaptasi format, karakteristik, dan bagian-bagian yang terdapat pada modul cetak pada umumnya. Akan tetapi akan terdapat beberapa perbedaan. Perbedaan antara modul cetak dan modul elektronik dapat dilihat pada tabel .1.

\section{Tabel 1 Perbedaan Modul Cetak dan Modul Elektronik}

\begin{tabular}{|c|c|}
\hline Modul Elektronik & Modul Cetak \\
\hline $\begin{array}{l}\text { Format elektronik (dapat } \\
\text { berupa file .doc, .exe, } \\
\text {.swf, dll) }\end{array}$ & $\begin{array}{l}\text { Format berbentuk } \\
\text { cetak (kertas) }\end{array}$ \\
\hline $\begin{array}{l}\text { Ditampilkan } \\
\text { menggunakan perangkat } \\
\text { elektronik dan software } \\
\text { khusus (laptop, PC, HP, } \\
\text { Internet) }\end{array}$ & $\begin{array}{l}\text { Tampilannya } \\
\text { berupa kumpulan } \\
\text { kertas yang tercetak }\end{array}$ \\
\hline $\begin{array}{l}\text { Lebih praktis untuk } \\
\text { dibawa }\end{array}$ & $\begin{array}{l}\text { Berbentuk fisik, } \\
\text { untuk membawa } \\
\text { dibutuhkan ruang } \\
\text { untuk meletakan }\end{array}$ \\
\hline $\begin{array}{l}\text { Biaya produksi lebih } \\
\text { murah }\end{array}$ & $\begin{array}{l}\text { Biaya produksi } \\
\text { lebih mahal }\end{array}$ \\
\hline $\begin{array}{l}\text { Tahan lama dan tidak akan } \\
\text { lapuk dimakan waktu }\end{array}$ & $\begin{array}{l}\text { Daya tahan kertas } \\
\text { terbatas oleh waktu }\end{array}$ \\
\hline $\begin{array}{l}\text { Menggunakan sumber } \\
\text { daya tenaga listrik }\end{array}$ & $\begin{array}{l}\text { Tidak perlu sumber } \\
\text { daya khusus untuk } \\
\text { menggunakannya }\end{array}$ \\
\hline $\begin{array}{l}\text { Dapat dilengkapi dengan } \\
\text { audio atau video dalam } \\
\text { penyajiannya }\end{array}$ & $\begin{array}{lr}\text { Tidak dapat } \\
\text { dilengkapi dengan } \\
\text { audio atau video } \\
\text { dalam penyajiannya }\end{array}$ \\
\hline
\end{tabular}

Modul elektronik dikembangkan dengan menggunakan software 3D PageFlip Professional. Menurut Amalia (2015) 3D PageFlip Professional adalah suatu software yang dapat dimanfaatkan untuk membuat bahan ajar berbentuk ebook digital dengan efek 3D. Software ini mampu mengubah bahan ajar berbentuk $P D F$ menjadi ebook $3 D$ flash yang menakjubkan dengan berbagai format seperti Exe, Zip, Html, 3D, screen Saver dan lain-lain. Dengan bahan ajar berbentuk $3 D$ Flash ini maka akan memberikan nuansa baru dalam proses pembelajaran di kelas karena 
guru maupun siswa dapat membaca dengan berbagai sudut dengan efek 3D. Software 3D PageFlip ini juga menyediakan pengaturan seperti magazine, dokumen dan sebagainya. Selanjutnya Salsabila (2013) menyebutkan bahwa 3D PageFlip Professional merupakan salah satu jenis perangkat lunak komputer yang dapat membuat tampilan animasi sehingga mampu menciptakan media pembelajaran interaktif bagi mahasiswa. Bahan ajar Modul Elektronik haruslah mampu memberikan informasi yang dibutuhkan oleh siswa sehingga diharapkan dapat menjadi penghubung anatara pengetahuan awal dan pengetahuan baru yang didapatkan oleh siswa tersebut.

Berdasarkan hasil observasi yang dilakukan peneliti pada 29 siswa dan satu guru Fisika dikelas XI MIPA 5 SMAN 1 Muaro Jambi, maka dapat dilihat bahwa pembelajaran fisika di SMAN 1 Muaro Jambi tidak terlepas dari penggunaan bahan ajar cetak seperti buku Fisika cetak berbasis kurikulum 2013 dan LKS. Dalam proses pembelajaran, guru Fisika di SMAN 1 Muaro Jambi beranggapan bahwa penggunaan bahan ajar belum maksimal untuk membantu siswa dalam memahami konsep Fisika, hal ini menyebabkan siswa merasa kurang termotivasi untuk mempelajari Fisika. Dari hasil observasi juga dapat diketahui bahwa sebanyak $75 \%$ siswa menganggap bahwa mata pelajaran Fisika itu sulit dan buku referensi yang digunakan disekolah hanya buku paket dan LKS, 70\% siswa memiliki komputer/laptop yang dapat digunakan sebagai penunjang pembelajaran mandiri, $90 \%$ siswa membutuhkan sumber belajar mandiri dan 93\% siswa menyetujui dengan adanya pembuatan e-modul pada materi Hukum Termodinamika.

Modul Elektronik perlu dikembangkan dengan pendekatan, metode ataupun model agar lebih terarah dan terstruktur karena adanya langkah-langkah dalam pembelajaran. Salah satu pendekatan yang diterapkan dalam Kurikulum 2013 adalah pendekatan saintifik. Pembelajaran dengan pendekatan saintifik adalah proses pembelajaran yang dirancang sedemikian rupa agar peserta didik secara aktif mengkonstruksi konsep, hukum atau prinsip melalui tahapan-tahapan pembelajaran yang melibatkan keterampilan proses seperti mengamati, mengklasifikasi, mengukur, meramalkan, menjelaskan, dan menyimpulkan.
Adapun Menurut Daryanto (2014) pendekatan saintifik dimaksudkan untuk memberikan pemahaman kepada peserta didik dalam mengenal, memahami berbagai materi menggunakan pendekatan ilmiah, bahwa informasi bisa berasal dari mana saja, dan kapan saja, tidak tergantung informasi searah dari guru. Karakteristik pembelajaran dengan pendekatan scientific menurut Daryanto (2014) adalah sebagai berikut:

a. Pembelajaran berpusat pada siswa.

b. Melibatkan keterampilan proses sains dalam mengkonstruksi konsep, hukum atau prinsip.

c. Melibatkan proses-proses kognitif yang potensial dalam meransang perkembangan intelek, khususnya keterampilan berfikir tingkat tinggi siswa.

d. Dapat mengembang karakter siswa.

Berdasarkan beberapa karakteristik diatas maka dapat disimpulkan bahwa karakteristik utama pembelajaran dengan pendekatan Scientific menuntut siswa untuk mendominasi proses pembelajaran dengan kerangka berfikir ilmiah sehingga menghasilkan peserta didik yang produktif, inovatif, kreatif, dan afektif. Seperti ditunjukkan bagan berikut



Gambar 1 hasil belajar melahirkan peserta didik yang produktif, kreatif, inovatif, dan afektif melalui penguatan sikap, keterampilan, dan pengetahuan yang terintegrasi

(Sumber: Daryanto, 2014)

Adapun langkah-langkah pembelajaran dengan pendekatan saintifik ialah sebagai berikut 
a. Mengamati

Kegiatan mengamati dalam pembelajaran sebagaimana diungkapkan dalam permendikbud Nomor 81a, hendaklah guru membuka luas dan bervariasi kesempatan peserta didik untuk melakukan pengamatan melalui kegiatan: melihat, menyimak, mendengar, dan membaca. Peran guru adalah sebagai fasilitator bagi siswa untuk melakukan pengamatan, melatih mereka untuk memperhatikan (melihat, membaca, mendengar) hal yang penting dari suatu benda atau objek. Kompetensi yang diharapkan adalah melatih kesungguhan, ketelitian dan mencari informasi.

b. Menanya

Kegiatan menanya dalam proses pembelajaran sebagaimana yang disampaikan dalam permendikbud Nomor 81a tahun 2013, adalah mengajukan pertanyaan tentang informasi yang tidak dipahami dari apa yang diamati atau pertanyaan untuk mendapatkan informasi tambahan tentang apa yang diamati. Kompetensi yang diharapkan dalam kegiatan ini adalah mengembangkan kreativitas, rasa ingin tahu, kemampuan merumuskan pertanyaan untuk membentuk pikiran kritis yang perlu untuk hidup cerdas dan belajar sepanjang hayat.

c. Mengumpulkan informasi

Dalam Permendikbud Nomor 81a tahun 2013, aktivitas mengumpulkan informasi dilakukan melalui eksperimen, membaca sumber lain selain buku teks, mengamati objek/kejadian/aktivias wawancara dengan nara sumber dan sebagainya

\section{d. Menalar}

Kegiatan menalar dalam proses pembelajaran sebagaimana dituangkan dalam Permendikbud Nomor 81a tahun 2013, adalah memproses informasi yang sudah dikumpulkan baik dari hasil kegiatan mengamati atau kegiatan mengumpulkan informasi.

e. Mengkomunikasikan

Mengkomunikasikan dalam kegiatan pembelajaran seperti yang diungkapkan dalam Permendikbud Nomor 81a tahun 2013, adalah menyampaikan hasil pengamatan, kesimpulan, berdasarkan hasil anlisis secara lisan, tertulis, atau media lainnya.

Pengembangan modul elektronik juga pernah dilakukan oleh Satriawati (2015), dengan judul "Pengembangan E-Modul Interaktif sebagai Sumber Belajar Elektronika
Dasar Kelas X SMKN 3 Yogyakarta". Pada saran penelitian di dalam penelitian tersebut diharapkan pada peneliti selanjutnya dapat mengembangkan isi modul yang diujicobakan tidak hanya satu kegiatan pembelajaran untuk mewakili proses pembelajaran serta dapat membuat modul elektronik pada materi pembelajaran fisika yang lain.

Penelitian ini bertujuan untuk mengembangkan modul elektronik dengan pendekatan saintifik sebagai penunjang pembelajaran fisika pokok bahasan Hukum termodinamika dan untuk mengetahui persepsi siswa terhadap modul leektronik tersebut. Adapun manfaat dari pengembangan yaitu dapat digunakan sebagai salah satu sumber belajar yang dapat memotivasi siswa dalam belajar fisika dan dapat digunakan sebagai media pembelajaran mandiri bagi siswa.

\section{Metode Penelitian}

Jenis Penelitian

Jenis penelitian ini adalah penelitian

dan pengembangan (Research and Development). Model pengembangan yang digunakan adalah model ADDIE yaitu singkatan dari analyze (analisis), design (desain), development (pengembangan), implementation (implementasi), dan evaluate (evaluasi) (Branch ,2009). Model ADDIE digunakan karena model ADDIE bertujuan untuk membuat bahan ajar.

\section{Waktu dan Temapat Penelitian}

Penelitian dilaksanakan di SMAN 1

Muaro Jambi pada tanggal 23 Mei 2017.

Subjek Penelitian

Subjek penelian ini terdiri dari siswa kelas XI MIPA 1 dan XI MIPA 5 SMAN 1 Muaro Jambi. Penelitian di kelas XI MIPA 1 yaitu untuk melihat persepsi siswa terhadap modul elektronik, sedangkan di kelas XI MIPA 5 yaitu untuk reliabilitas angket.

Prosedur Pengembangan

Prosedur pengembangan bahan ajar berupa modul elektronik dengan pendekatan saintifik pokok bahasan Hukum Termodinamika ini hanya dibatasi pada tahap development (pengembangan). 




Gambar 2. Tahap Pengembangan Model ADDIE

(Sumber: Branch 2009)

1) Analisis

Tahap pertama yang dilakukan dalam mengembangkan modul elektronik yaitu analisis. Analisis dilakukan dengan observasi awal untuk mengidentifikasi fakta-fakta yang ada dalam proses pembelajaran. Tahapan analisis yang dilakukan untuk mengidentifikasi fakta-fakta adalah sebagai berikut:

1. Memvalidasi Kesenjangan Kinerja

Berdasarkan hasil observasi dari data angket yang peneliti lakukan di kelas XI MIPA 5 SMAN 1 Muaro Jambi, didapatkan informasi adanya permasalahan dalam proses belajar mengajar fisika di kelas tersebut, permasalahan yang dihadapi yaitu sulitnya beberapa siswa memahami materi Hukum Termodinamika yang disebabkan oleh kurangnya bahan ajar yang digunakan.

2. Menetapkan Tujuan

Setelah menemukan masalah maka langkah selanjutnya dari tahapan analisis adalah menetapkan tujuan. Tujuan ditetapkan berdasarkan silabus pembelajaran fisika yang digunakan di SMAN 1 Muaro Jambi. Dimana di dalam penelitian ini peneliti menetapkan untuk membuat modul elektronik dengan pendekatan saintifik menggunakan $3 D$ PageFlip Propessional yang diharapkan dapat membantu proses belajar mengajar di sekolah dan membantu untuk memberi solusi terhadap masalah yang ditemukan dalam kegiatan memvalidasi kesenjangan kinerja.

3. Menganalisis Peserta Didik

Tujuan dilakukannya analisis peserta didik adalah untuk mengetahui kemampuan awal, pengalaman, hal yang disukai, dan motivasi pembelajaran siswa dalam proses belajar mengajar.

\section{Sumber Daya yang Tersedia}

Sumber daya yang harus dianalisis, yaitu sumber daya dari segi fasilitas instruksional, dan sumber daya manusia yang mempengaruhi desain, pengembangan, dan penerapan dalam pembelajaran.

5. Menyusun Rencana Kerja

Terdapat tiga rencana kerja yang disusun oleh pengembang. Pertama, pengidentifikasian produk yang akan dikembangkan. Kedua, perhitungan lamanya pengembangan. Ketiga, pengembang menganalisis biaya pengembangan mulai dari buku-buku acuan pembuatan modul elektronik, penyusunan produk awal, produk hasil revisi, dan modul elektronik akhir.

2) Perancangan (Design)

1. Adapun storyboard modul elektronik yang dibuat sebagai berikut:

A. Desain awal sampul modul



B. Tampilan awal halaman judul kegiatan

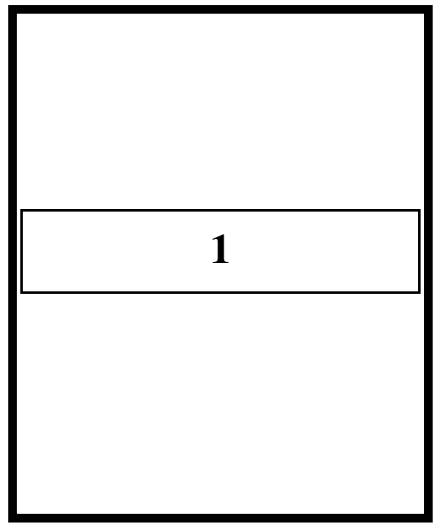


C. Tampilan awal uraian materi, rangkuman dan latihan

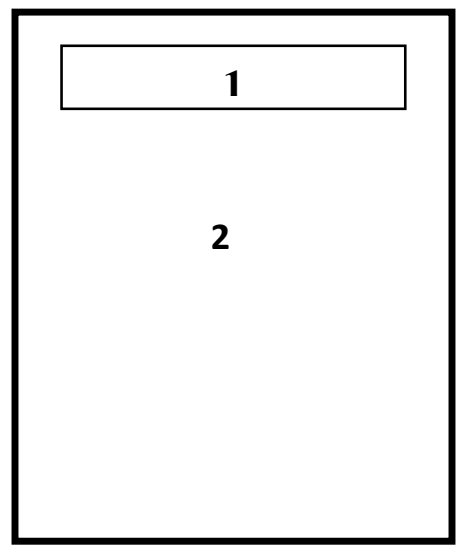

D. Tampilan awal cover belakang



3) Pengembangan (Development)

Tahap pengembangan merupakan tahap pembuatan modul elektronik menggunakan aplikasi 3D Pageflip Professional. Modul elektronik yang dibuat disesuaikan dengan desain yang telah dirancang. Hal-hal yang terlebih dahulu dilakukan dalam pembuatan modul elektronik yaitu mengumpulkan materi pembelajaran yang akan disajikan, gambar, video, dan animasi yang berkaitan dengan materi. Untuk menambah ketertarikan siswa dalam mempelajari mata pelajaran fisika pokok bahasan Hukum Termodinamika.

Setelah seluruh bahan yang diperlukan terkumpul, maka langkah selanjutnya yang dilakukan adalah membuat modul elektronik dengan aplikasi pengembangnya yaitu $3 D$ Pageflip Professional. 3D Pageflip Professional ini dipilih karena terdapat fitur aplikasi yang berbentuk buku sungguhan, dengan tampilan video dan animasi dalam bentuk 3D.

\section{4) Evaluasi}

Evaluasi pada pengembangan ini ada disetiap tahapan mulai dari analisis, desain dan pengembangan. Evaluasi digunakan untuk menilai proses dan produk yang dibuat.

\section{Uji Coba Produk}

Uji coba produk merupakan bagian dari pengembangan. Adapun tahapan-tahapan pada uji coba produk ialah :

1. Pembuatan modul elektronik.

2. Memvalidasi modul elektronik sampai modul elektronik dinyatakan layak untuk digunakan

3. Menguji cobakan modul elektronik yaitu di SMAN 1 Muaro Jambi, pengujicobaan ini dilakukan pada dua kelas yaitu dikelas XI MIPA 1 dan XI MIPA 5 dimana data yang dimabil yaitu reliabilitas angket dikels XI MIPA 5 dan persepsi siswa dikels XI MIPA 1

Jenis Data

Jenis data yang digunakan pada penelitian pengembangan ini bersifat kualitatif dan kuantitatif. Data kualitatif yang diambil adalah saran dari tim validasi ahli, sedangkan data kuantitatif yang diambil adalah anket validasi ahli dan angket persepsi siswa. Data yang diperoleh dari hasil pengembangan produk ini digunakan sebagai dasar dalam menetapkan kelayakan modul elektronik ini.

\section{Instrumen Pengumpulan Data}

Adapun instrumen pengumpulan data yang digunakan antara lain.

\section{Observasi}

Observasi biasa diartikan sebagai pengamatan dan pencatatan secara sistematik terhadap unsur-unsur yang nampak dalam suatu gejala pada objek penelitian (Widoyoko, 2016). Metode observasi ini digunakan untuk melihat dan mengamati secara langsung keadaan di lapangan agar memperoleh gambaran yang lebih luas tentang permasalahan yang akan dilakukan.

\section{Telaah Dokumen}

Metode ini merupakan suatu cara pengumpulan data yang dilakukan dengan menganalisis isi dokumen yang berhubungan dengan masalah yang diteliti (Widoyoko,2016). Metode ini digunakan untuk mengumpulkan data yang telah tersedia dalam catatan dokumen seperti silabus, rpp, dan 
bahan ajar yang digunakan oelh guru mata pelajaran fisika di SMA 1 Muaro Jambi.

\section{Angket Kebutuhan siswa}

Pada angket kebutuhan siswa berisikan tentang aspek-aspek yang berhubungan dengan keadaan pembelajaran fisika serta hal-hal yang dibutuhkan dalam pembelajaran fisika.

\section{Angket Validasi Ahli Media}

Pada angket validasi ahli media berisikan tentang aspek-aspek yang berhubungan dengan media yang telah dikembangkan meliputi desain sampul modul, desain isi modul, desain software modul, komponen penyajian, dan kemudahan pengoperasian.

\section{Angket Validasi Ahli Materi}

Pada angket validasi ahli materi berisikan tentang aspek-aspek yang berhubungan dengan materi modul elektronik meliputi kesesuaian materi dengan tujuan pembelajaran, ketepatan materi dan isi, dan komponen kebahasaan.

\section{Angket Persepsi siswa}

Pada angket persepsi siswa berisikan tentang aspek-aspek yang berhubungan dengan modul elektronik yang telah dikembangkan meliputi desain sampul modul, desain isi modul, desain software modul, komponen penyajian, kemudahan pengoperasian, dan komponen kebahasaan.

\section{Analisis Instrumen Penelitian}

\section{Analisis validitas}

Validitas adalah keadaan yang menggambarkan tingkat instrumen yang bersangkutan mampu mengukur apa yang akan diukur. Untuk menguji validitas instrumen penelitian digunakan korelasi produk moment atau metode Pearson, dengan rumus sebagai berikut (Arikunto, 2013).

$$
r_{x y}=\frac{N \sum x y-\left(\sum x\right)\left(\sum y\right)}{\sqrt{\left.\left\{N \sum x^{2}-\left(\sum x\right)^{2}\right\}, N \sum y^{2}-\left(\sum y\right)^{2}\right\}}}
$$

Keterangan:

$r_{x y} \quad=$ koefisien korelasi antara $\mathrm{x}$ dan $\mathrm{y}$

$N \quad=$ jumlah subjek

$\Sigma x y=$ jumlah perkalian antara skor $\mathrm{x}$ dan

skor $\mathrm{y}$

$\Sigma x \quad=$ jumlah total skor $\mathrm{x}$

$\Sigma y \quad=$ jumlah total skor $\mathrm{y}$

$\Sigma x^{2} \quad=$ jumlah dari kuadrat $\mathrm{x}$

$\Sigma y^{2} \quad=$ jumlah dari kuadrat $\mathrm{y}$
$(\Sigma x)^{2}=$ jumlah nilai $\mathrm{x}$ kemudian dikuadratkan

$(\Sigma y)^{2}=$ jumlah nilai $\mathrm{y}$ kemudian dikuadratkan

\section{Analisis reliabilitas}

Reliabilitas menunjuk pada satu pengertian bahwa sesuatu instrumen cukup dapat dipercaya untuk digunakan sebagai alat pengumpul data karena instrumen tersebut sudah baik. Dalam penelitian ini untuk mengukur reliabilitas ditentukan dengan rumus Cronbach Alpha sebagai berikut (Arikunto, 2013).

$$
r_{11}=\left(\frac{n}{n-1}\right)\left(1-\frac{\Sigma \sigma_{i}^{2}}{\sigma_{t}^{2}}\right)
$$

Dengan:

$$
\sigma_{t}^{2}=\frac{\Sigma X^{2}-\frac{(\Sigma X)^{2}}{N}}{N}
$$

Keterangan:

$r_{11} \quad=$ indeks korelasi (harga reliabilitas)

$n \quad=$ banyaknya butir soal

$\Sigma \sigma_{i}^{2} \quad$ jumlah varians butir.

$\sigma_{t}^{2} \quad=$ varians total.

$N \quad=$ banyak peserta yang mengisi angket

$X \quad=$ skor yang diberikan

\section{Teknik Analisis Data}

1. Analisis data kualitatif

Teknik analisis data dalam penelitian kualitatif yang berupa observasi dan saran drai validator dilakukan secara deskriptif kualitatif.

a. Observasi

- Reduksi data

Observasi dilakukan dengan cara mengumpulkan data secara langsung dengan menggunakan angket kebutuhan siswa yang terdiri dari 17 item pertanyaan, data yang didapat dari 17 item pertanyaain direduksi menjadi beberapa item pertanyaan yang sesuai dengan permasalahan penelitian yaitu pengembagan bahan ajar yang berupa modul elektronik.

- Penyajian data

Data yang telah direduksi disajikan dalam bentuk presentase dan dilihat seberapa besar tanggapan yang mendukung ataupun 
yang menolak akan pengembangan modul elektronik.

- Penarikan kesimpulan

Berdasarkan data yang telah disajikan maka dapat ditarik kesimpulan bahwa responden menyetujui ataupun menolak akan pengembangan modul elektronik, data kualitatif pada tahapan ini disajikan dalam tahap analyze.

b. Saran dari validator ahli media dan ahli materi

- Reduksi data

saran dari validator ahli media dan ahli materi ditulis terlebih dahulu dalam bentuk teks selanjutnya data yang berbentuk teks direduksi misalnya per indikator pada angket validasi ahli media dan ahli materi.

- Penyajian data

Data yang telah direduksi selanjutnya disajikan dalam bentuk deskripsi, dari deskripsi tersebut maka dapat dilihat bahwa valaidator menyatakan layak atau belum layak modul elektronik dapat digunakan sebagai sumber belajar mandiri bagi siswa.

- Penarikan kesimpulan

Setelah data disajikan maka ditarik kesimpulan bahwa validator menyatakan layak atau belum layak digunakan sebagai salah satu sumber belajar yang bisa digunakan oleh siswa, data kualitatif pada tahapan ini disajikan dalam tahap development.

\section{Analisis data kuantitatif}

Teknik analisis data dalam penelitian kuantitatif yang berupa skor validasi ahli media, validasi ahli materi dan persepsi siswa dilakukan secara statistik deskriptif dan disajikan dalam tabel. Langkah-langkah menganalisis data kuantitatif tersebut adalah sebagai berikut:

a. Mengkuantitatifkan hasil checking dengan memberi skor sesuai dengan bobot yang telah ditentukan sebelumnya.

Tabel 2. Interval Skala Likert

\begin{tabular}{cc}
\hline Respons & Bobot Skor \\
\hline Sangat Baik & 4 \\
Baik & 3 \\
Tidak Baik & 2 \\
Sangat Tidak Baik & 1 \\
\hline (Sumber: Direktorat Pembinaan SMA, 2010)
\end{tabular}

b. Menentukan skor rata-rata indikator yang diberikan berdasarkan penilaian dari validasi ahli media, validasi ahli materi, dan persepsi siswa.

$$
\bar{X}=\frac{\sum X}{n}
$$

Keterangan:

$\bar{X} \quad=$ Mean

$\sum X=$ jumlah skor jawaban responden (validator)

$\mathrm{N}=$ jumlah responden (validator)

c. Menentukan varians dan standar deviasi sampel.

$$
\begin{gathered}
s^{2}=\frac{\sum(x i-\bar{x})^{2}}{(n-1)} \\
s=\sqrt{\frac{\sum(x i-\bar{x})^{2}}{(n-1)}}
\end{gathered}
$$

Keterangan

$$
\begin{array}{ll}
s & =\text { varians kelompok data } \\
s^{2} & =\text { standar deviasi kelompok } \\
\mathrm{n} & =\text { jumlah responden (validator) }
\end{array}
$$

d. Mengidentifikasi kecenderungan ubahan setiap sub variabel digunakan rata-rata ideal (Xi) dan standar deviasi ideal (SDi), dapat dihitung dengan acuan norma yaitu:

Xideal $=\frac{1}{2}$ (skor tertingi + skor terendah)

SDideal $=\frac{1}{6}$ (skor tertinggi - skor terendah)

e. Kemudian setiap sub variabel dikategorikan menjadi empat kategori dan diubah menjadi data kualitatif sebagai berikut :

Tabel 3. Rentang Skor dan Kriteria Kualitatif

\begin{tabular}{cc}
\hline Rentang Skor & Kriteria \\
\hline$X i+1,5 S D i \leq \bar{X} \leq X i+3,0 S D i$ & Sangat \\
$X i+0 S D i \leq \bar{X}<X i+1,5 S D i$ & Baik \\
$X i-1,5 S D i \leq \bar{X}<X i+0 S D i$ & Tidak \\
& Baik \\
$X i-3 S D i \leq \bar{X}<X i-1,5 S D i$ & Sangat \\
tidak Baik
\end{tabular}

(Sumber: Direktorat Pembinaan SMA, 2010) 


\section{Hasil dan Pembahasan}

Modul elektronik didesain dan dikembangkan berdasarkan hasil yang diperoleh dari tahapan observasi awal sampai pada tahapan desain. U ntuk menyesuaikan apa yang dibutuhkan siswa dengan apa yang telah dikembangkan, maka dilakukan validasi sebanyak 2 kali. Validasi yang dilakukan yaitu validasi materi dan validasi media. Validasi dilakukan oleh 2 orang dosen Pendidikan Fisika Universitas Jambi. Validator akan memberikan saran, kritikan terhadap modul elektronik yang dikembangkan. Validasi dilakukan sampai validator menyatakan bahwa modul elektronik telah layak digunakan tanpa revisi.

1. Validasi Materi

Pada validasi materi tahap I, berdasarkan angket yang diberikan, validator menyarankan:

1. Menambahkan contoh soal yang sesuai dengan materi dan dapat mengukur kompetensi keberhasilan siswa.

2. Menyesuaikan gambar dan grafik dengan materi

3. Menyesuaikan animasi dan video dengan materi.

4.

Hasil validasi ahli materi tahap I dapat dilihat pada tabel 4 berikut.

Tabel 4. Validasi ahli materi tahap I

\begin{tabular}{|c|c|c|}
\hline Indikator & Skor & Ket. \\
\hline $\begin{array}{l}\text { Kesesuaian } \\
\text { materi dengan } \\
\text { tujuan } \\
\text { pembelajaran }\end{array}$ & 3 & Baik \\
\hline $\begin{array}{l}\text { Ketepatan materi } \\
\text { dan isi }\end{array}$ & 12 & $\begin{array}{l}\text { Tidak } \\
\text { Baik }\end{array}$ \\
\hline $\begin{array}{l}\text { Komponen } \\
\text { kebahasaan }\end{array}$ & 9 & Baik \\
\hline $\begin{array}{l}\text { Indikator } \\
\text { Keseluruhan }\end{array}$ & 24 & Baik \\
\hline
\end{tabular}

Setelah seluruh saran dari validator diperbaiki, maka pada validasi tahap kedua semua validator menyatakan modul elektronik telah layak dan dapat digunakan. Hasil validasi ahli materi tahap II dapat dilihat pada tabel 5 berikut.
Tabel 5. Validasi ahli materi tahap II

\begin{tabular}{ccc}
\hline Indikator & Skor & Ket. \\
\hline $\begin{array}{c}\text { Kesesuaian } \\
\text { materi dengan } \\
\text { tujuan }\end{array}$ & 3 & Baik \\
$\begin{array}{c}\text { pembelajaran } \\
\text { Ketepatan materi } \\
\text { dan isi }\end{array}$ & 16 & Baik \\
$\begin{array}{c}\text { Komponen } \\
\text { kebahasaan } \\
\text { Indikator }\end{array}$ & 9 & Baik \\
Keseluruhan & 28 & Baik \\
\hline
\end{tabular}

2. Validasi Media

Pada validasi media tahap I, berdasarkan angket yang diberikan, validator menyarankan:

1. Menggunakan layout yang sesuai dengan judul dan materi yang digunakan.

2. Membuat layout yang sesuai dengan materi

3. Membuat layout kegiatan pembelajaran yang konsisten.

4. Menggunakan gradasi warna.

5. Memperjelas tampilan grafik.

6. Mencari animasi dan video yang sesuai dengan materi.

7. Mengganti warna layout yang relevan.

8. Menggunakan warna yang transparan.

9. Tidak menggunakan tombol yang ketika ditampilkan di infokus jadi besar.

Hasil validasi ahli media tahap I dapat dilihat pada tabel 6 berikut.

Tabel 6. Validasi ahli media tahap I

\begin{tabular}{ccc}
\hline Indikator & Skor & Ket. \\
\hline $\begin{array}{c}\text { Desain Sampul } \\
\text { Modul }\end{array}$ & 9 & Baik \\
$\begin{array}{c}\text { Desain Isi Modul } \\
\text { Desain Software } \\
\text { Modul }\end{array}$ & 21 & Baik \\
$\begin{array}{c}\text { Komponen } \\
\text { Penyajian }\end{array}$ & 9 & $\begin{array}{c}\text { Tidak } \\
\text { Baik }\end{array}$ \\
$\begin{array}{c}\text { Kemudahan } \\
\text { pengoperasian }\end{array}$ & 3 & Baik \\
$\begin{array}{c}\text { Indikator } \\
\text { keseluruhan }\end{array}$ & 53 & Baik \\
\hline
\end{tabular}


Setelah seluruh saran dari validator diperbaiki, maka pada validasi tahap kedua semua validator menyatakan modul elektronik telah layak dan dapat digunakan. Hasil validasi ahli media tahap II dapat dilihat pada tabel 7 berikut.

Tabel 7. Validasi ahli media tahap II

\begin{tabular}{ccc}
\hline Indikator & Skor & Ket. \\
\hline $\begin{array}{c}\text { Desain Sampul } \\
\text { Modul }\end{array}$ & 12 & Baik \\
Desain Isi Modul & 30 & $\begin{array}{c}\text { Sangat } \\
\text { Baik }\end{array}$ \\
$\begin{array}{c}\text { Desain Software } \\
\text { Modul } \\
\text { Komponen } \\
\text { Penyajian }\end{array}$ & 12 & Baik \\
$\begin{array}{c}\text { Kemudahan } \\
\text { pengoperasian } \\
\text { Indikator } \\
\text { keseluruhan }\end{array}$ & 3 & Baik \\
\hline
\end{tabular}

Setelah selesai divalidasi oleh dosen, tahap selanjutnya adalah melakukan uji coba modul elektronik pada siswa kelas XI MIPA 1 dan XI MIPA 5 SMAN 1 Muaro Jambi. Hasil uji coba pada siswa X1 MIPA 5 digunakan untuk menentukan reliabilitas angket, sedangkan hasil uji coba siswa kelas XI MIPA 1 digunakan untuk menentukan persepsi siswa terhadap modul elektronik yang dikembangkan. Uji reliabilitas dilakukan dengan menggunakan program SPSS dengan mengacu pada persamaan Alfa Cronbach, sehingga diperoleh nilai reliabilitas angket sebesar $r_{11}=0.850$ dengan kategori reliabilitas sangat tinggi. Dari perhitungan tersebut, dapat disimpulkan bahwa angket dapat dipercaya dan dapat digunakan untuk mengambil data terhadap kelayakan modul elektronik yang telah dikembangkan.

Setelah didapat nilai reliabilitas angket yang digunakan, kemudian dilakukan uji coba untuk melihat kelayakan modul elektronik. Uji coba dilakukan pada siswa kelas XI MIPA 1, di mana data yang diambil adalah persepsi siswa terhadap modul elektronik yang telah dikembangkan. Angket yang digunakan terdiri dari 6 indikator penilaian yaitu desain sampul modul, desain isi modul, desain software modul, komponen penyajian ,kemudahan pengoperasian, dan komponen kebahasaan. Enam indikator ini terdiri dari 22 penyataan.
Berdasarkan angket persepsi siswa, didapatkan hasil persepsi siswa terhadap pengembangan modul elektronik sebagai berikut:

Tabel 8. Hasil persepsi siswa terhadap pengembangan modul elektronik

\begin{tabular}{|c|c|c|}
\hline Indikator & Skor & Ket. \\
\hline $\begin{array}{l}\text { Desain Sampul } \\
\text { Modul }\end{array}$ & 13,04 & $\begin{array}{c}\text { Sangat } \\
\text { Baik }\end{array}$ \\
\hline Desain Isi Modul & 23,50 & $\begin{array}{c}\text { Sangat } \\
\text { Baik }\end{array}$ \\
\hline $\begin{array}{c}\text { Desain Software } \\
\text { Modul }\end{array}$ & 13,07 & $\begin{array}{c}\text { Sangat } \\
\text { Baik }\end{array}$ \\
\hline $\begin{array}{l}\text { Komponen } \\
\text { Penyajian }\end{array}$ & 3,39 & $\begin{array}{c}\text { Sangat } \\
\text { Baik }\end{array}$ \\
\hline $\begin{array}{l}\text { Kemudahan } \\
\text { pengoperasian }\end{array}$ & 3,32 & $\begin{array}{c}\text { Sangat } \\
\text { Baik }\end{array}$ \\
\hline $\begin{array}{l}\text { Komponen } \\
\text { Kebahasaan }\end{array}$ & 16,75 & $\begin{array}{c}\text { Sangat } \\
\text { Baik }\end{array}$ \\
\hline $\begin{array}{l}\text { Indikator } \\
\text { keseluruhan }\end{array}$ & 72,53 & $\begin{array}{c}\text { Sangat } \\
\text { Baik }\end{array}$ \\
\hline
\end{tabular}

Berdasarkan tabel 7 dapat disimpulkan bahwa modul elektronik yang telah dikembangkan dikategorikan memiliki kelayakan yang sangat baik. Hasil ini dihitung berdasarkan rumus yang di ambil dari Juknis Penilaian Afektif dengan menggunakan skala 4.

Hal tersebut dapat dilihat dari skor yang didapatkan untuk indikator desain sampul modul dengan 4 pernyataan sebesar 13,04 dalam kategori sangat baik, indikator desain isi modul dengan 7 pernyataan sebesar 23,50 dalam kategori sangat baik, indikator desain software modul dengan 4 pernyataan sebesar 13,07 dalam kategori sangat baik, indikator komponen penyajian dengan 1 pernyataan sebesar 3,39 dalam kategori sangat baik, indikator kemudahan pengoperasian dengan 1 pernyataan sebesar 3,32 dalam kategori sangat baik, serta indikator komponen kebahasaan dengan 5 pernyataan sebesar 16,75 dalam kategori sangat baik, dan untuk hasil persepsi siswa secara keseluruhan dengan 22 indikator pernyataan sebesar 72,53 dalam kategori sangat baik.

\section{Spesifikasi}

1. Modul elektronik yang dibuat merupakan bahan ajar Fisika yang dikembangkan 
dengan menggunakan aplikasi $3 D$ PageFlip Profesional.

2. Format akhir dari modul elektronik ini yaitu dalam format exe.

3. Kerangka modul terdiri dari cover modul, peta kedudukan modul, kegiatan pembelajaran per sub bab dengan contoh dan latihan soal serta tes formatif akhir.

4. Materi hukum termodinamika disajikan secara mendalam yang dilengkapi dengan persamaan yang jelas, video, gambar, grafik, animasi, simulasi, contoh soal, dan soal latihan yang dapat membantu dalam proses pembelajaran

5. Kegiatan pembelajaran dalam modul elektronik menggunakan pendekatan siantifik

6. Tingkat pengguna aplikasi: SMA/MA Kelas XI

Keunggulan

Keunggulan yang terdapat pada modul elektronik yaitu:

1. Modul elektronik ditampilkan dalam bentuk tiga dimensi.

2. Kegiatan pembelajarn disusun agar siswa dapat mengkonstruksi konsep, hukum dan prinsip melalui tahapan pembelajaran.

3. Materi hukum termodinamika disusun secara mendalam yang dapat membantu siswa dalam proses pembelajaran.

4. Dapat menggunakan modul elektronik tanpa memiliki aplikasinya.

Kelemahan

Kelemahan yang terdapat pada modul elektronik yaitu:

1. Hanya terdapat satu simulasi yaitu pada kegiatan pembelajaran satu

2. Tidak ada video dan animasi dikegiatan pembelajaran tiga.

3. Belum bisa terkoneksi dengan internet.

4. Tidak bisa digunakan pada windows 7 kecuali ada Adobe Flash Player.

5. Belum bisa digunakan pada smartphone.

Kajian Produk Akhir

Adapun kajian produk akhir dari modul elektronik yang telah dikembangkan sebagai berikut:
1. Cover modul elektronik

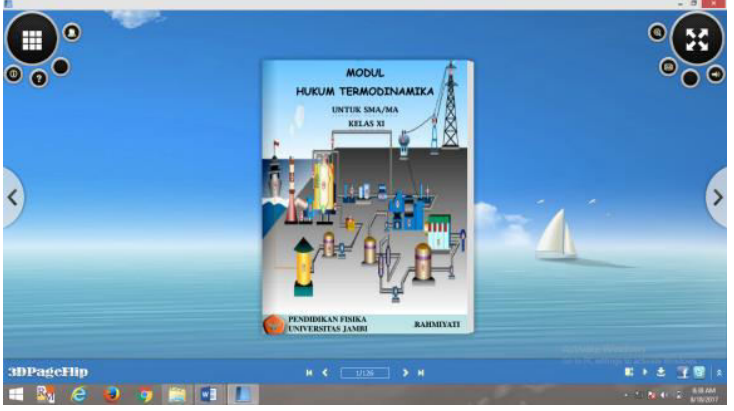

2. Profil penulis

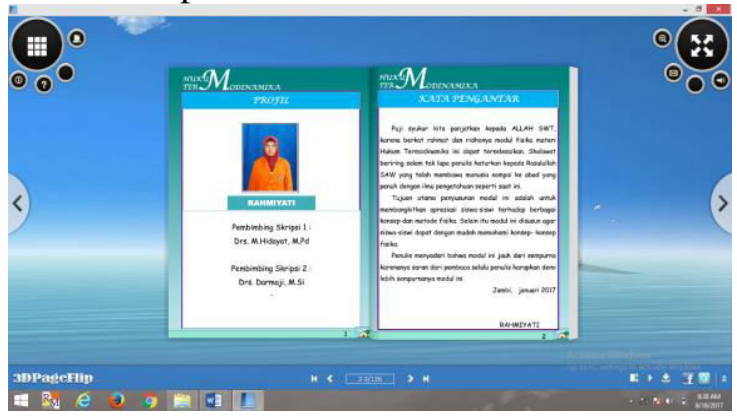

3. Kata pengantar modul elektronik

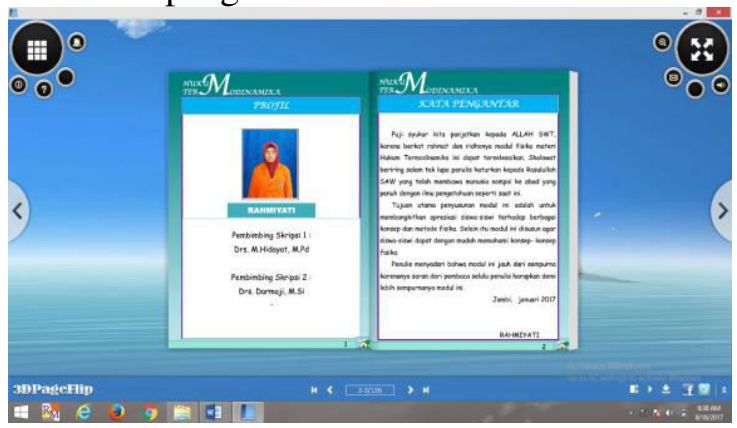

4. Daftar isi modul elektronik

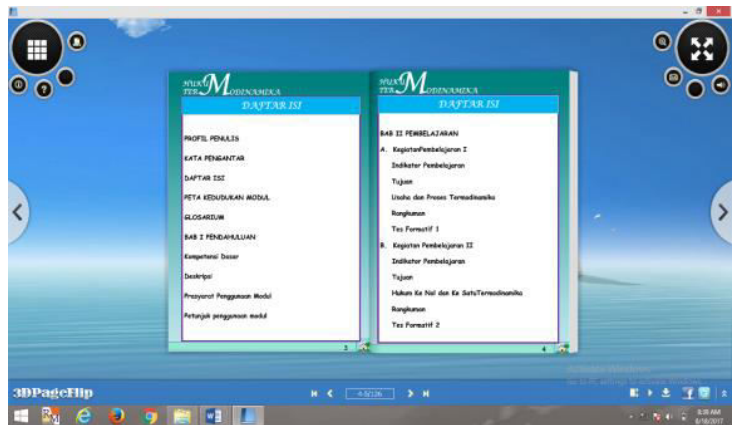


5. Peta kedudukan modul elektronik

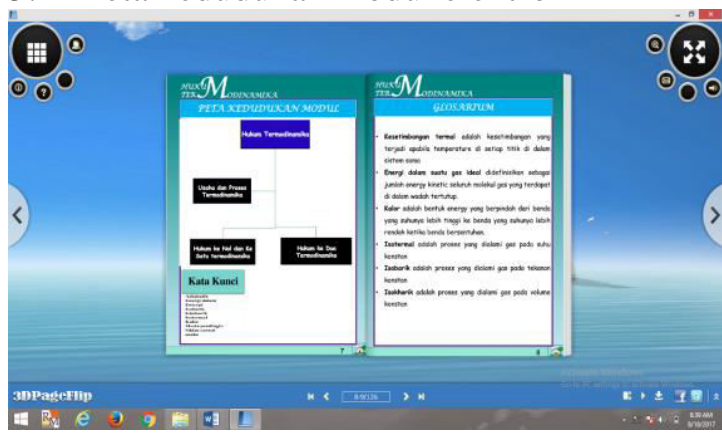

6. Pendahuluan modul elektronik

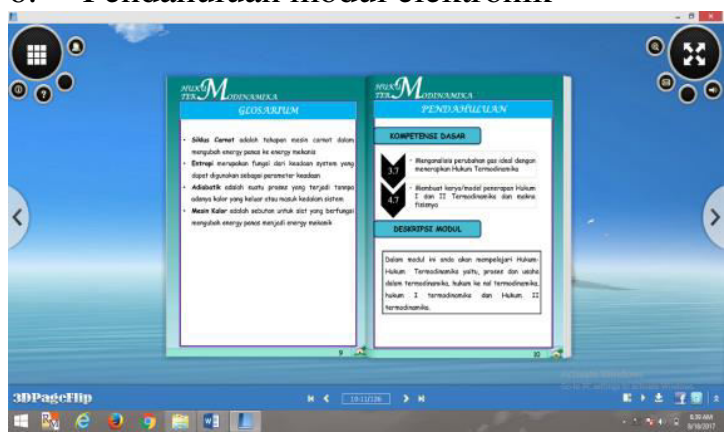

7. Petunjuk penggunaan modul elektronik



8. Bagian awal kegiatan pembelajaran

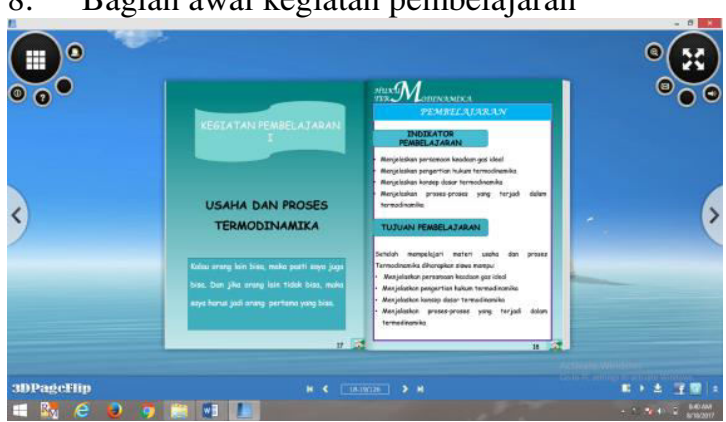

9. Tampilan materi pembelajaran

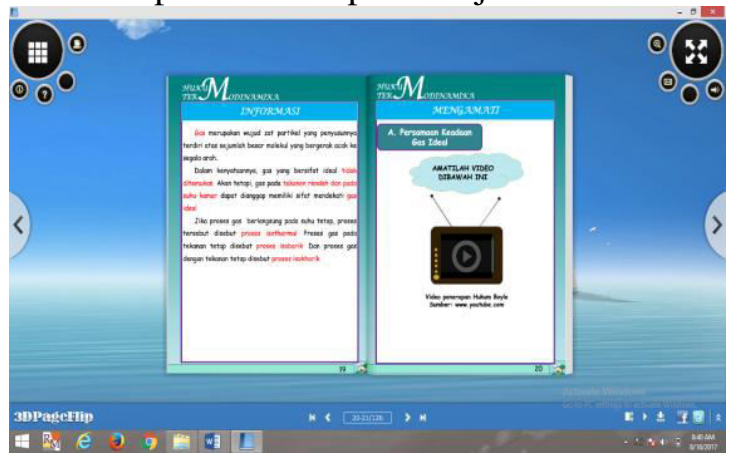

10. Rangkuman modul elektronik



11. Tampilan latihan soal



12. Tampilan tes formatif akhir

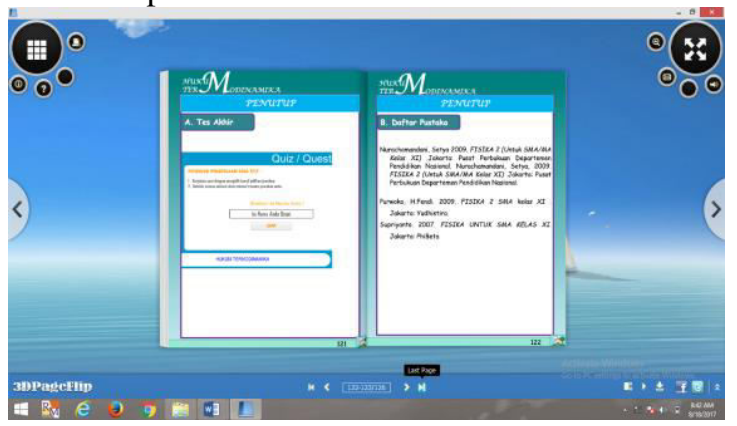




\section{Simpulan dan Saran}

Simpulan

Berdasarkan hasil pengembangan dan uji coba modul elektronik maka dihasilkan modul elektronik dengan pendekatan saintifik pokok bahasan Hukum Termodinamika untuk SMA/MA kelas XI yang valid dan layak digunakan.dengan skor ahli materi sebesar 28 dan ahli media sebesar 69 yang termasuk dalam kategori baik dan sangat baik. Produk yang dihasilkan memiliki spesifikasi antara lain software menggunakan $3 D$ PageFlip Professional, format akhir program exe, kerangka modul tediri dari cover modul, peta kedudukan modul, kegiatan pembelajaran per sub bab dengan contoh dan latihan soal serta tes formatif akhir, kegitan pembelajaran modul disusun dengan pendekatan saintifik, materi disajikan dengan persamaan yang jelas, gambar, grafik, video, animasi, simulasi, contoh soal dan latihan soal. Adapun keunggulan yang terdapat pada modul elektronik yaitu modul ditampilkan dalam bentuk tiga dimensi, kegiatan pembelajaran disusun agar siswa dapat mengkonstruksi konsep, hukum atau prinsip melalui tahapan pembelajaran. Kelemahan pada modul elektronik yaitu hanya terdapat satu simulasi dikegiatan pembelajaran satu, tidak ada video dan animasi dikegiatan pembelajaran tiga, belum bisa terkoneksi dengan internet dan belum bisa digunakan pada smartphone Hasil persepsi siswa terhadap modul elektronik yaitu 72,53 dan dikategorikan sangat baik.

Saran

Saran yang dapat diberikan oleh peneliti bagi peneliti berikutnya adalah:

1. Menambahkan simulasi, video dan animasi pada setiap kegiatan pembelajaran.

2. Mengujicobakan modul elektronik untuk mengetahui keefektifan modul.

3. Mengaktifkan koneksi internet agar siswa dapat mengakses video, simulasi dan animasi yang berhubungan dengan materi Hukum Termodinamika.

4. Membuat modul elektronik untuk materi yang lainnya.

\section{Daftar Pustaka}

Arikunto, Suharsimi. 2013. Dasar-Dasar Evaluasi Pendidikan. Jakarta: Bumi Aksara.

Amalia, Rizqi. 2015. Pengembangan Buku Pintar Elektronik (BPE) Berbasis 3D PageFlip Pada Tema Cita-Citaku Kelas IV DI SD IT Al-Kamilah I Banyumanik. Semarang: Universitas Negeri Semarang

Branch, Robert Maribe. 2009. Instructional Design: The ADDIE Approach. USA: Department of Educational Psychology and Instructional Technology University of Georgia

Daryanto, 2013. Menyusun Modul Bahan Ajar untuk Persiapan Guru dalam Mengajar. Yogyakarta: Gava Media.

Daryanto, 2014. Pendekatan Pembelajaran Saintifik kurikulum 2013. Yogyakarta: Gava Media.

Direktorat Pembinaan SMA. 2010. JUKNIS PENYUSUNAN PERANGAT PENILAIAN AFEKTIF DI SMA. Jakarta: Kementerian Pendidikan Nasional

Hidayatullah, Rahmat. 2014. Pengembangan Lembar Kerja Siswa untuk Meminimalisir Miskonsepsi Fisika Siswa SMA, Skripsi, Universitas Pendidikan Indonesia, Bandung.

Rijal, B.S. 2014. Pengembangan Modul Elektronik Perakitan dan Instalisasi Komputer Sebagai Sumber Belajar untuk Kelas X SMK PIRI I Yogyakarta, Skripsi, Universitas Negeri Yogyakarta, Yogyakarta.

Salsabila, R.P. 2013. Pengembangan Modul Elektronik Fisika sebagai Media Intruksional Pokok Bahasan Hukum Newton pada Pembelajaran Fisika di SMA. Jurnal Pembelajaran Fisika, 1(1): 12-19.

Satriawati, Helna. 2015. Pengembangan EModul Interaktif sebagai Sumber Belajar Elektronika Dasar Kelas X SMKN 3 
Yogyakarta. Skripsi, Universitas

Yogyakarta

Sugianto, Dony dkk, 2013. Modul Virtual: Multimedia FlipBook Dasar Teknologi Digital. Jurnal INVOTEC, 9(2): 110-116

Sulistyarini, E. 2015. Pengembangan Bahan Ajar Fisika SMA Materi Gelombang Bunyi Berbasis Interactive PDF, Skripsi, Universitas Negeri Semarang, Semarang.

Sugiyono. 2016. Statistika untuk Penelitian. Bandung: Alfabeta

Widoyoko, S. E. P. 2016. Teknik Penyusunan Instrumen Penelitian. Yogyakarta: Pustaka Belajar 